(ISSN - 2752-7018)

VOLUME 02 ISSUE 01 Pages: 43-56

SJIF IMPACT FACTOR (2021: 5 . 376)

OCLC -1276789625 METADATA IF -7.569

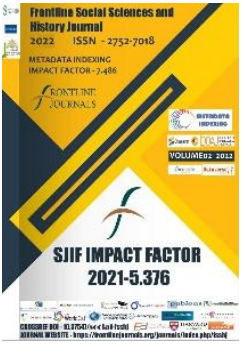

Journal Website: https://frontlinejournal s.org/journals/index.ph $\mathrm{p} /$ fsshj

Copyright: Original content from this work may be used under the terms of the creative commons attributes 4.0 licence.
Research Article

\section{IMPORTANT FEATURES OF SOCIO-ETHICAL VIEWS OF KHOJA AHROR VALI}

Submission Date: January 11, 2022, Accepted Date: January 21, 2022,

Published Date: January 31, 2022

Crossref doi: https://doi.org/10.37547/social-fsshj-02-01-06

\section{Rakhmatova Kholida Kholikovna}

Senior Lecturer, Candidate Of Philosophical Sciences Bukhara Institute Of Engineering And Technology, Uzbekistan

\title{
Abstract
}

The article analyzes the beginning of the reform of the Naqshbandi doctrine of active participation in social and political life, the abolition of the opposition between the state and religion at the initiative of the Sufi, the system of protection of the Sufi. It has been analyzed that the teachings of Sufism are in line with the philosophy of compromise.

\section{KEYWORDS}

Opposition, reconciliation, kingdom, sect, philosophy of compromise, social protection system.

\section{INTRODUCTION}


(ISSN - 2752-7018)

VOLUME 02 ISSUE 01 Pages: 43-56

SJIF IMPACT FACTOR (2021: 5. 376)

OCLC -1276789625 METADATA IF -7.569

In the second half of the 15th century, the attitude of the Naqshbandi sect towards statesmen changed radically. The change in Naqshbandi's policy towards the rulers is related to the activities of Hoja Ahror Wali. Sources explain that the essence of this change was the transition from opposition to reconciliation. That is, from the time of Hoja Ahror Wali, it was in the interests of the sect and the people in the broadest sense, to renounce the opposition of the sect to the rulers, the contradictions and intolerance that prevailed between the sect and the state, and to establish relations with them. For the first time in its three-century history, Naqshbandi turned to states and rulers, established relations with them, and moved on to cooperation. This new, positive relationship, established between the sect and the state, has a broad meaning, encompassing all forms and types, including communication, dialogue, consultation, consultation, agreement, cooperation, and so on. In the sources on Naqshbandi, the relationship between the sect and the state, which arose due to Hoja Ahror Wali, is expressed by the broad concept of "conflict".[1,2,3]
Hoja Ahror Wali's relationship with the statesmen led to a new approach to the issue of Naqshbandi's attitude to the state, a new position towards it. In other words, this turning point in the Naqshbandi activity, developed and carried out by Hoja Ahror Wali, was of strategic importance to the sect. This change, which was of great political and social significance in the history of Naqshbandi, was a positive event in the sect, more precisely, a reform event. However, in order to assess this radical change in the history of Naqshbandi as a positive event, an act of reform in the sect, it is first necessary to determine the causes and goals of its occurrence. The pamphlet Tanbiyat us-salotin by Makhdumi Azam Dahbedi is a great help in solving this problem. Mahdumi Azam (1461-1542), who led the Naqshbandi sect in Samarkand in the first half of the 16th century after Khoja Ahror Wali, spoke in detail about the relationship between the sect and the state. After Hoja Ahror Wali, all the leaders of Naqshbandi accepted his opinion on the need to cooperate with the rulers and acted as a new program of the sect, maintaining close relations with the statesmen in the interests of the sect and the people.[4,5,6,7] 
(ISSN - 2752-7018)

VOLUME 02 ISSUE 01 Pages: 43-56

SJIF IMPACT FACTOR (2021: 5. 376)

OCLC -1276789625 METADATA IF -7.569

Hoja Ahror Wali did not suddenly raise the idea of this progressive reform, which led to a change in the strategy of the sect. Before realizing the need to build a relationship with the statesmen, he thought long and hard about this problem. Mahdumi Azam, pointing out that this idea was first raised by Hoja Ahror Wali, wrote that it was difficult:, the true subhona and the Almighty made me responsible for quarreling with the kings". Thus, in dealing with kings, alleviating the burden of the people was the main goal of Hodja Ahror Wali's lifelong noble intentions and constant aspirations, a noble desire, gnosis and social activity that occupied his entire mind.

Until Hoja Ahror Wali came to the historical arena, it referred to the ongoing opposition between the sect and the state and official clergy. Hoja Ahror Wali, realizing the main reason why the sect was not sufficiently developed and not widespread, was determined to resolve the ongoing disputes and disagreements between the sect and the state. The Sufi saw this conflict as a major obstacle to the development of the sect, and devoted all his efforts and activities to overcoming this obstacle, to approach the rulers, to follow the path of conflict, to compromise and to cooperate.

One of the glorious goals of Hoja Ahror Wali, who grew up in the spirit of Naqshbandi's humanistic teachings and always lived with the grief of the poor, was to call them to justice and civility through conflict with kings and statesmen. The mystic's conflict with the kings provided a real opportunity to achieve this goal. While in conflict with the rulers, Hoja Ahror Wali sought to influence them, to instill in them a sense of civic duty, and to encourage them to treat the citizens fairly. It is known that he honorably fulfilled his main task - to persuade kings to the path of justice, and devoted all his thoughts and activities to this goal. So, his goal in entering the path of conflict with the kings was both the development of religion and the Shari'a, and the prosperity of the world. The most noble goal of Hoja Ahror Wali was to establish peace and stability in the country by directing the rulers in governing the country in the interests of the people, resolving disputes between the ruling group and the citizens and the king.

The event of Hoja Ahror Wali to be in conflict with the kings was aimed not only at cooperation 
(ISSN - 2752-7018)

VOLUME 02 ISSUE 01 Pages: 43-56

SJIF IMPACT FACTOR (2021: 5. 376)

OCLC -1276789625 METADATA IF -7.569

\section{Crossref $d$

Publisher: Frontline Journals

between the sect and the state, but also at ensuring peace and stability in society as a whole. The cooperation of Khoja Ahror Wali and later Naqshbandi leaders with the kings allowed the rulers to use the intelligence and prudence of the leaders of the sect, their laduniy (inner) knowledge capable of anything out of the ordinary for the benefit of the country and the people. Hence, the new policy of dealing with kings, which was the product of the intellect of Hoja Ahror Wali, served both the development of the sect and the interests of the country and the people. $[8,9,10]$

The path of conflict with the kings revealed by Hoja Ahror Wali led to the development and prestige of the sect and opened the way for the rulers to have a positive influence, to control their state activities on the basis of justice towards the citizens. This event gave a social character to the religious and mystical activity of Hoja Ahror Wali, turning the leader of the sect into a great public figure. The sect, on the other hand, became connected with society and secular life and became a major socio-political force. The event of conflict with the kings stemmed from the motto of the "dialogue method" of
Naqshbandi, developed it, raised it to the level of active participation in socio-political life, participation in state affairs.

Hoja Ahror Wali more accurately expressed the political activism of the Naqshbandi sect in the 15th century, and more importantly, applied it in practice. According to the sources, Hodja Ahror Wali said: "The sheikhs before us did not address the emirs and kings on public concerns. And we are constantly working on it ... We consider it necessary".

Hoja Ahror Wali connects his involvement in politics with the "deterioration of the times." Therefore, it is preferable to be in the palace of the ruler in order to help the people, to raise the religion of the prophets to the highest peak, and thus to go to the ruler, because he knows that his throne may seem insignificant in the face of the glory of faith. At the heart of such considerations lies the peace and tranquility of the community.

The letters of Hoja Ahror Wali reflect that he was a supporter of peace, harmony, and just kings. As we look at the contents of Letter No. 500 (506) in the Compendium of Reconciliation, we see that it is aimed at exempting the population from the 
(ISSN - 2752-7018)

VOLUME 02 ISSUE 01 Pages: 43-56

SJIF IMPACT FACTOR (2021: 5. 376)

OCLC -1276789625 METADATA IF -7.569

"nomadic" tax. asked me to ask you to get rid of the "nomenclature" (tax). I urge you to save your memory if you focus on it. I am sure you will not hesitate to intercede for him".[11,12,13]

"Nombardor" or "Madad-i nombardor" are people who were recruited to march around the king during the military campaigns in the 15th century. Later, this method became an emergency cash tax and was recorded in a special ledger and collected from the population each year. In the letter, Hoja Ahror Wali asks the authorities to exempt the victim from the "nombardar" tax.

In the 13th letter of the Compendium of Reconciliation, he tells the kings that the way to find true happiness is to alleviate the people's worries and anxieties, and urges them not to forget the interests of the people.

In his letters, Hoja Ahror Wali emphasized the interests of ordinary, poor people, repeatedly emphasizing that the peace of the country depends, first of all, on the well-being of the people and the harmony of their way of life. This can be seen in the content of the letters of Khoja Ahror Vali to Abdurahman Jami and Alisher
Navoi. When Alisher Navoi wanted to resign from the palace, he wrote a letter to Navoi's teacher Abdurahman Jami, asking him to persuade him not to leave the palace for the good of the people:

"After the declaration of need, it is said: Please, Mr., from time to time, in honor of the service of Mr. Mawlana Alisher, and remind this poor man in his memory, let them do it. Because what is done for the good of Muslims is in fact the good of both worlds".

Abdurahman Jami has repeatedly commented on this to Alisher Navoi, but the complicated political situation, the riots in Hussein Boykaro's palace, the quarrels between the sultans and even the sultan and his sons Badiuzzaman and other princes have made Alisher Navoi very tired and the palace service The opinion that the opinion of the mystic Jami was also less comforting to Alisher Navoi, and that Jami again appealed to Khoja Ahror Wali for a solution to this issue, is included in the "Comprehensive Conciliation". In this, the piri komil Abdurahman Jami relied on the high prestige of Khoja Ahror Wali, the leader of the sect and the politician of the time. Hoja Ahror Wali sent a letter to Alisher 
(ISSN - 2752-7018)

VOLUME 02 ISSUE 01 Pages: 43-56

SJIF IMPACT FACTOR (2021: 5. 376)

OCLC -1276789625 METADATA IF -7.569

\section{Crossref $d$



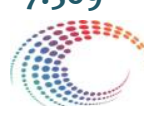

metadatด

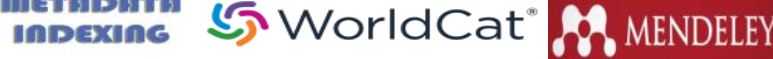

Publisher: Frontline Journals

Navoi on this issue with the following content: Our request is that if you do not remember the idea of staying away from that service in order to help the Muslims, we hope that with your help the memory of a poor person will be saved from sorrow and joy will appear in his heart. At the same time, in times of trouble, his mood and mood increase, and in this regard, his faith in God increases. At a time when no one pays attention to human suffering, it is the noblest activity to pursue the interests of Muslims".

This letter proves once again that Hoja Ahror Wali had a great influence in the political life of that time. The letter was not addressed to an ordinary citizen, but to the Prime Minister, the most respected scholar, poet Alisher Navoi. In this, Hoja Ahror Wali, who believed in the power of his influence, was not mistaken. According to sources, Alisher Navoi accepted the request of Khoja Ahror Wali in the letter and served for a long time in the palace of Hussein Boykaro. As we read the letters, we are convinced that the leaders of the sect, Alisher Navoi and Abdurahmon Jami, have always been committed to alleviating the people's worries and anxieties.
Hoja Ahror Wali knew that a mature man should help the people and also intervene in the affairs of the sultans to alleviate their burden. A mature person must have the power to control the power of all political institutions for a noble purpose such as serving the people, to have the rank and status of a reputable and influential person. After Hoja Ahror Wali, almost all the figures of Naqshbandi followed his motto of conflict with the kings and were in close contact with the rulers.[14,15,16]

We want to analyze the social protection system that played an important role in the activities of Hoja Ahror Wali. Sources indicate that Hoja Ahror Wali was engaged in farming at the age of twenty-nine to earn an honest living. At that time, their crops were so prosperous that they appointed a representative to manage them and became a large landowner. They said, "Our wealth is for the poor. This is the uniqueness of so many goods".

According to the sources, the economic activity of Hoja Ahror Wali soon developed very widely. It is noteworthy that the research revealed that small landowners transferred their lands to Hoja Ahror Wali to avoid taxes. The authority of Hoja 
(ISSN - 2752-7018)

VOLUME 02 ISSUE 01 Pages: 43-56

SJIF IMPACT FACTOR (2021: 5. 376)

OCLC -1276789625 METADATA IF -7.569

\section{Crossref $d$

Publisher: Frontline Journals

Ahror Wali before the rulers protected them from imposing emergency taxes on the necks of the workers, in addition to what is prescribed in the Shari'ah (tithes, zakat). This factor was also one of the reasons for the increase in the lands of Hoja Ahror Wali. In addition to farming and animal husbandry, Hoja Ahror Wali had handicraft rastas and workshops in the cities, from which he made a large income.

In terms of trade, Hoja Ahror Wali traded not only in the territory of Movarounnahr, but also in Khorasan, India. It should also be noted that Hoja Ahror Wali spent most of his income from economic activities such as paying heavy taxes per capita and carrying out religious and cultural constructions. For example, when Umarshaikh Mirza demanded a tax of 250,000 dinars from the people of Tashkent, Khoja Ahror Vali paid all the money himself and handed over another 70,000 dinars to the tax collectors.

It is known from sources that madrasas were built by Khoja Ahror Vali in Samarkand, Tashkent and Kabul. Important information about the madrasas and mosques built by Khoja Ahror Vali in Tashkent is also given in the work "Tarihi jadidai Tashkent". Three copies of this work, including the author's signature, are kept only in Tashkent. "Tarihi jadidai Tashkent" contains a lot of information about the history of the Kokand khanate, especially the city of Tashkent, including the madrasah and mosques of Khoja Ahror Vali in Tashkent.

Although Khoja Ahror Vali spent most of his life in Samarkand, he also took an active part in the cultural and spiritual life of Tashkent. Not only in the 15th century, but also in the following centuries, his personality left a big mark on the spiritual environment of Tashkent. The madrassas and mosques in Tashkent named after Khoja Ahror Vali are proof of this. The play depicts the appearance of these madrasas and mosques in the XIX century.[17,18,19]

In the work "Tarihi jadidai Tashkent" we find some information about the activities of Khoja Ahror Wali. For example, according to the author, the land east of Kokaldosh Madrasa and between the Main Street was understood to be the birthplace of Hoja Ahror Wali, and it was called "Hoja Ahror Wali Square". In 1274/1857, the governor of Tashkent, Ahmad Kushbegi, built a separate dome and madrasah at the birthplace of Khoja Ahror Wali. This madrasa was called 
(ISSN - 2752-7018)

VOLUME 02 ISSUE 01 Pages: 43-56

SJIF IMPACT FACTOR $(2021: 5 \cdot 376)$

OCLC -1276789625 METADATA IF -7.569

\section{Crossref doi g1 Google

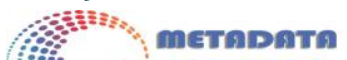 \\ indexing 5) WorldCat" fô MENDELEY \\ Publisher: Frontline Journals}

Muyi Mubarak. The madrasa, built by Khoja Ahror Wali in 1451, consisted of 20 rooms, a classroom and a mosque, according to Muhammad Salihhoja. According to the "Historical Jadidai Tashkent", in addition to this madrasah, Khoja Ahror Wali built a dome in the chillakhana of the mausoleum of Sheikh Khovand Tahur and placed a stone slab in the middle of it.
In his research on the life and work of the German scholar Jürgen Paul Hoja Ahror Wali, he makes a special study of the social protection system of Sufism. Based on this research, we have classified the protection system of Hoja Ahror Wali as follows: 1) Spiritual - spiritual protection; 2) Economic protection; 3) Sociopolitical protection.

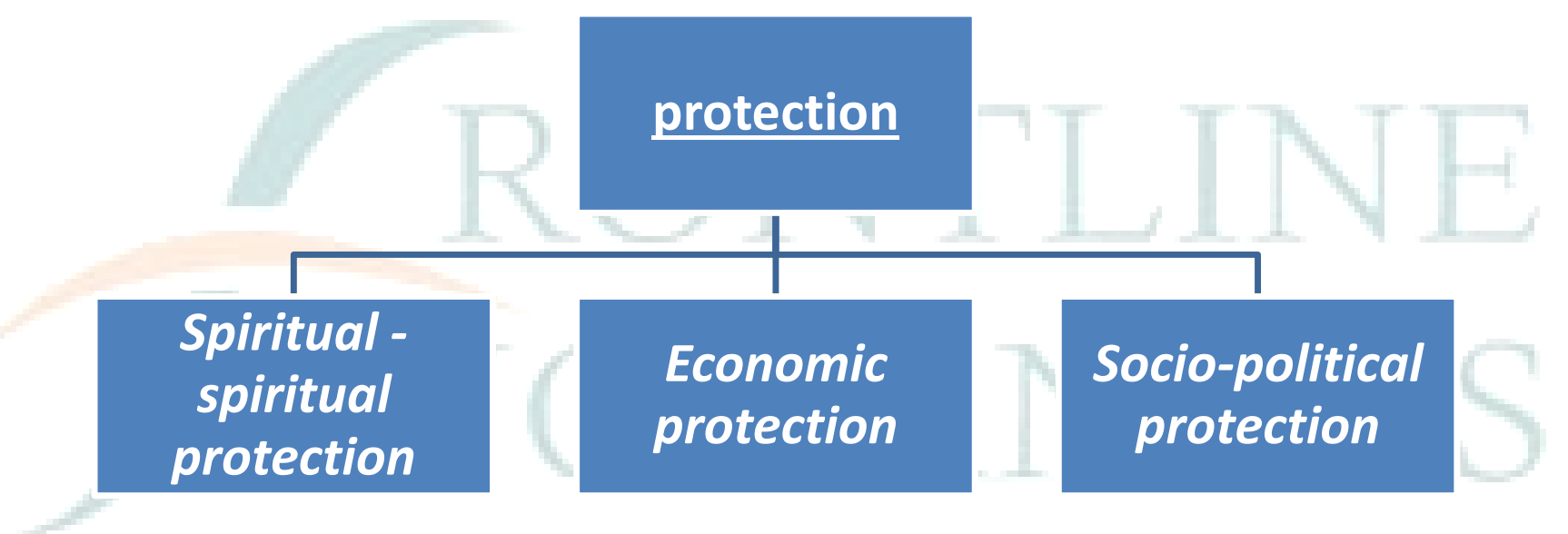

sheikhs, and it is the power of protection that protects them from prejudices and prejudices. For example, one of the disciples of Hoja Ahror Wali was a disciple of another sheikh before he became a murid to that person, and when Hoja Ahror joined the Wali, he feared that the previous sheikh might be cursed. But Hoja Ahror Wali was convinced that the greatness of the power of protection is that only spiritual protection can save from any harm.

Although Hoja Ahror Wali was the leader of the sect, he combined a large economic sector into his influence. He has opened shops and enterprises in Turkestan, Movarounnahr, Khorasan and a number of other cities. Sources say that Hoja Ahror Wali also had velvet 
(ISSN - 2752-7018)

VOLUME 02 ISSUE 01 Pages: 43-56

SJIF IMPACT FACTOR (2021: 5. 376)

OCLC -1276789625 METADATA IF -7.569

factories. People who were with Hoja Ahror Wali would have the opportunity to act as both a religious representative and an entrepreneur. The Muhavvata-iy Mulloyon complex has combined these two directions to a high degree.[20,21,22,23]

Muhavvata-iy Mulloyon was a spiritualadministrative, central, organizational structure. The fact that Hoja Ahror Wali unites hundreds of servants, slaves and other people on the lands of the waqf testifies to the existence of a perfect structure of governance. Other centers of the sect consisted of madrasas, founded by Khoja Ahror Vali in Samarkand and Tashkent. In addition to the centers, many people were spiritually connected with Hoja Ahror Wali.

It is worth mentioning that Hoja Ahror Wali, who was able to change the destiny and destiny of several thousand people in the direction of hope and happiness, is a perfect man who is one of the jewels of history as a man of high humanity, kindness and generosity. While gaining a reputation as a murshid of the Sufi Naqshbandi doctrine, he still shines with the rays of his civic ideas.
Summarizing the views of Hoja Ahror Wali on peace, harmony and social protection, the following can be noted:

- In Naqshbandi doctrine, reform was initiated by Hoja Ahror Wali for active participation in social and political life;

- Hoja Ahror Wali first demonstrated the role of a sectarian as a public figure in the Naqshbandi doctrine and expanded his scope of action as an active human being;

- Khoja Ahror Wali's relationship with the statesmen led to a new approach to the issue of Naqshbandi's attitude to the state, to a new position towards him. This turning point in the Naqshbandi activity, developed and carried out by Hoja Ahror Wali, was of great importance to the sect;

- Hoja Ahror Wali believed that it was impossible to continue the activity of the sect without the help of kings. He therefore advocated rapprochement, compromise, and cooperation with the rulers. It can be said that the way developed by Hoja Ahror Wali made a turn in the doctrine of Naqshbandi; 
(ISSN - 2752-7018)

VOLUME 02 ISSUE 01 Pages: 43-56

SJIF IMPACT FACTOR (2021: 5. 376)

OCLC -1276789625 METADATA IF -7.569

- At the initiative of Hoja Ahror Wali, the opposition between the state and the clergy was put to an end;

- The protection system of Hoja Ahror Wali was a strong social protection made for the people. Sufism protected the people economically, socio-politically, spiritually and enlightenment. Hoja Ahror Wali devoted all his energy and potential to reconciling with the kings of the time in order for the people to live in peace, harmony, harmony and stability. Hoja Ahror Wali prevented possible wars.

- In the example of Hoja Ahror Wali, it is clear that sponsorship is not only economic support, but also a system of spiritual, sociopolitical significance.

- Hoja Ahror Wali is known in history as a great landowner, but used his property for the economic protection of the people.[24,25]

\section{REFERENCES}

1. Мирзиёев Ш.М. Миллий тараққиёт йўлимизни қатъият билан давом эттириб, янги босқичга кўтарамиз. - Тошкент: “Ўзбекистон” НМИУ, 2017. - 1-жилд. - 592 б.

2. Мирзиёев Ш.М. Миллий тикланишдан - миллий юксалиш сари. - Тошкент: Ўзбекистон, НМИУ, 2020. 4-жилд - 456 б.

3. Ўзбекистон Республикаси Президенти Шавкат Мирзиёевнинг Ўзбекистон ёшлари форумида сўзлаган нутқи // Халқ сўзи, 2020, 26 декабрь.

4. Ўзбекистон

Республикаси

Президенти Шавкат Мирзиёевнинг Олий Мажлисга мурожаати // Халқ сўзи, 2020, 30 декабрь.

5. Navruzova G.N. Khojagon education and the cpecifics of this way. ACADEMICIA An International Multidisciplinary Research Journal. ISSN: 2249-7137 Vol.11, Issue1, January 2021 Impact Factor: SJIF 2021=7.492 1131-1137. 
(ISSN - 2752-7018)

VOLUME 02 ISSUE 01 Pages: 43-56

SJIF IMPACT FACTOR (2021: 5. 376)

OCLC - 1276789625 METADATA IF -7.569

6. Navruzova G.N. Bahauddin

Naqshband-the seventh pir of

Bukharai Sharif (Noble Bukhara).

Islom tafakkuri (Maxsus son) 2020. B.

5-8.

7. Navruzova G.N., Ubaidova V.E.

Pharaoh of the weavers of Bahauddin Naqshband. Academicia. An International Multidisciplinary Research Journal. Vol. 10 issue 5, May 2020. Impact Factor: SJIF 2020=7.13. 922-926 pages.

8. Наврўзова Г., Зоиров Э. Бухорои Шарифнинг етти пири. Тошкент: Muharrir, 2018. 80.

9. Shodiyev Jahongir. Philosophical views of Umar life // Doi Number: $10.5958 / 2249-$

7137.2020.00127.5.p.360.

10. Навруцзова Г.Н., Рахматова X. Нақшбандия тушунчалари генезиси. Бухоро: “Бухоро, 2010. 150 б.

11. Назаров қ. Жахон фалсафаси қомуси. 1-китоб - Тошкент:
«Маънавият» нашриёти, 2019. - 920 б.

12. Назаров Қ. Жахон фалсафаси қомуси. 2-китоб - Тошкент: «Маънавият» нашриёти, 2019. - 856 б.

13. Jahongir Shodiev. The problem of knowledge in the philosophical views of Umar Khayyam // Imam al-Bukhari IBS Journal №2 2021. -B. 128.

14. Хожа Убайдуллох Ахрор. Фақаротул-орифийн. Табаррук рисолалар../ Таржимонлар Махмуд Хасаний, Бахриддин Умрзоқ, Хамидуллох Амин. Т.; Адолат. 2004. - Б. 13.

15. Саъдиев Садри. Нақшбандия тариқатининг улуғ ислохотчиси. // Сино. -Тошкент, 2004. -№ 13. - Б.21.

16. Холмўминов Жаъфар. Вахдат улвужуд фалсафаси ва Нақшбандия таълимоти (Ибн-ал-Арабий, Хожа Мухаммад Порсо, Хожа Ахрор Валий ва Мавлоно Абдурахмон Жомий қарашлари асосида). Монография. / Масъул мухаррир: Н.Жўраев. - Т.: "Yangi nashr", 2020. - 324 бет. 
(ISSN - 2752-7018)

VOLUME 02 ISSUE 01 Pages: 43-56

SJIF IMPACT FACTOR (2021: 5. 376)

OCLC -1276789625 METADATA IF -7.569

Publisher: Frontline Journals

17. Алишер Навоий. Насойим - ул мухаббат. Т.2001. 20 - томлик. 17том. 280 - б.

18. Кньш А.Д. Мусульманский мистицизм. Москва - СанктПетербург. “Диля",

19. 19.Rakhmatova Kholida Kholikovna, THE WORLD IMPORTANCE OF THE TEACHINGS OF KHOJA AHROR VALI.

20. ACADEMICIA An International Multidisciplinary Research Journal (Double Blind Refereed \& Peer Reviewed Journal)

21. Шодиев Ж.Ж. Умар Хайёмнинг асосий асарлари ва рубоийларининг тузилиши, мазмуни ва тахлили // Илм Сарчашмалари. - Урганч, 2020. - № 10. - Б. 44-47

22. Шодиев Ж.Ж. Умар Хайём рубоийларининг талқин ва тавсифи // Наманган давлат университети Илмий ахборотномаси. - Наманган, 2020. № 9. - Б. 206-210.
23. Шодиев Ж.Ж. Умар Хайёмнинг ижтимоий - ахлоқий қарашлари // Фалсафа ва хуқуқ. - Тошкент, 2020. - № 3. - Б.107-110.

24. Шодиев Ж.Ж. Interpretation of the image of may in the ruba of Umar Khayyam // Monografia pokonferencyjna science, research, development \#33. -Paris, 29.09.202030.09.2020. - P. 126-133.

25. Шодиев Ж.Ж. Умар Хайём фалсафий қарашларида инсон тақдири ва эркин ирода масаласи // Наманган давлат университети Илмий ахборотномаси. -Наманган, 2020. № 2. - Б. 197-204.

26. Shodiev J.J. Interpretation of moral facts in the opinions of Umar Khayyam // International engineering journal for research \& development. - India, Vol. 5 Issue 3, April 2020 -P. 143-148. (Impact Factor SJIF 2020=6.549)

27. K.S.Rakhmonov. Influence of leavens of spontaneous fermentation and phytoadditives on the provision of microbiological safety of bread // T. I. 
(ISSN - 2752-7018)

VOLUME 02 ISSUE 01 Pages: 43-56

SJIF IMPACT FACTOR (2021: 5. 376)

OCLC -1276789625 METADATA IF -7.569

Publisher: Frontline Journals

Atamuratova, N. R. Djuraeva, I. B.

Isabaev, L. N. Haydar-Zade//Journal of

Critical Reviews //2020, Vol.7, Issue

5, pp. 850-860.

28. S.K. Jabborova.Application of products of processing mulberries and roots of sugar beet in the production of cupcakes // I.B.Isabaev., N.R. Djuraeva., M.T. Kurbanov.,l.N. Khaydar-Zade., K.S. Rakhmonov //Journal of Critical Reviews //2020, Vol.5, Issue 5, pp. 277-286.

29. K.S.Rakhmonov. Application of phito supplements from medicinal vegetable raw materials in the production of drugs // T. I. Atamuratova., M.E. Mukhamedova., N.K.Madjidova., $\quad$ I.Sh. Sadikov //Journal of Critical Reviews //2020, Vol.7, Issue 12, pp. 934-941.

30. Djurayeva N, Mixtures of Vegetable Fat as a Potential Raw Material for Bakery// Barakayev N, Rakhmonov K,Atamuratova T, Mukhamedova $\mathrm{M}$, Muzaffarova Kh. // International Journal of Current Research and
Review// october 2020, Vol.12, Issue 19, pp. 140-148. DOI: http://dx.doi.org/10.31782/IJCRR.20 20.12192

31. Djurayeva N, Plant-fat mixtures as a potential raw material for bakery production// Rakhmonov $\mathrm{K}$, Barakayev N, Atamuratova $\mathrm{T}$, Mukhamedova M, Muzaffarova Kh. // Plant Cell Biotechnology and Molecular Biology 2020 21(45-46), pp. $29-42$

32. Ravshanov S.S, The impact of ultrasonic activated water on hydrothermal processing of wheat grains grown in dry climate conditions // Rakhmonov K.S., Amanov B.N. // Plant Cell Biotechnology and Molecular Biology 2020 21(45-46), pp. $29-42$

33. Kuliev N.SH, Udk 664.8 baking properties and quality expertise wheat flour// Rakhmonov K.S. // European Journal of Molecular \& Clinical Medicine, 2020, Volume 7, Issue 2, Pages 6333-6340 
(ISSN - 2752-7018)

VOLUME 02 ISSUE 01 Pages: 43-56

SJIF IMPACT FACTOR (2021: 5. 376)

OCLC -1276789625 METADATA IF -7.569

Publisher: Frontline Journals

34. Ravshanov S.S, The Effect Of Drinking And Activated Water On Field Scales

Of Wheat Grains Grown In Arid Climatic Conditions// Rakhmonov K.S. Ergasheva H.B., Yuldasheva Sh. J.// European Journal of Molecular \& Clinical Medicine, 2020, Volume 7, Issue 3, Pages 3065-3070.

35. Rakhmonov K.S., Confectionery Products for Therapeutic and Preventive Purpose with Medicinal Herbs Uzbekistan// L.N. KhaydarZade., N.SH. Kuliev, G.H.Sulaymonova // Annals of the Romanian Society for Cell Biology, Vol. 25, Issue 2, 2021, Pages. $4126-4140$.
36. Ravshanov S.S., Influence of the Use of Activated Water during Hydrothermal Treatment on the Quality of Bread// Rakhmonov K.S., Radjabova V.E., Pardayev Z.T. // Annals of the Romanian Society for Cell Biology, Vol. 25, Issue 2, 2021, Pages. $4091-4102$

37. Azim Oltiev., The role of catalysts in fat transesterification technology// Matluba Kamalova., Kakhramon Rakhmonov., Orifjon Mamatqulov// IOP Conf. Series: Earth and Environmental Science 848(2021) 012220 